\title{
Correction to: Apatinib: A Review in Advanced Gastric Cancer and Other Advanced Cancers
}

\author{
Lesley J. Scott ${ }^{1}$
}

Published online: 4 May 2018

(C) Springer International Publishing AG, part of Springer Nature 2018

\section{Correction to: Drugs}

https://doi.org/10.1007/s40265-018-0903-9

An Online First version of this article was made available online at http://link.springer.com/journal/40265/ onlineFirst/page/1 on 16 April 2018. Errors were subsequently identified in the article, and the following corrections should be noted:

\section{- Rewording in main text}

Section 1, Introduction, paragraph 3, line 1: The following line, which previously read:
“Apatinib [AiTan ${ }^{\mathrm{TM}}$ (China); Rivoceranib® (global)] is a"

Should read:

"Apatinib [Aitan ${ }^{\circledR}$ (brand name in China)], also known as rivoceranib, is a"

The original article has been updated.

The original article can be found online at https://doi.org/10.1007/ s40265-018-0903-9.

Lesley J. Scott

demail@springer.com

1 Springer, Private Bag 65901, Mairangi Bay, Auckland 0754, New Zealand 